\title{
Současná česká religiozita v generační perspektivě
}

\section{Current Czech religiosity in the generational perspective}

\author{
Marie Laudátová, Roman Vido
}

\begin{abstract}
This paper focuses on religiosity of the Czech population with respect to its distribution according to generational criteria. It tries to connect findings from sociology of religion with generational perspective based on sociology of knowledge (Mannheim). Our analysis draws on the empirical data from the three waves of European Values Study survey (1991, 1999 and 2008) and derives from a basic assumption that religiosity of a person is decisively formed by the social and historical conditions of the era of his/her socialization and, thus, by his/her belonging to a generation in a sociological sense. We expect that taking the generational aspect into account may help us a lot with understanding and explanation of the patterns of contemporary Czech religiosity.
\end{abstract}

KEY WORDS Czech Republic, generation, history, religiosity, socialization, transmission, values

\section{Úvod}

Téma generací dnes zažívá nejen v odborném, ale i veřejném diskurzu výrazné oživení. Např́iklad v souvislosti s kohortami mladých lidí, kteří nyní vstupují na pracovní trh, kde na ně čeká v lepším případě pouze práce ,,prekérní“, v horším případě žádná, se dnes můžeme setkat s označením „generace Y“ (v USA) či „ztracená generace“ (v Evropě). Menší pozornosti se generačnímu pohledu dostává v souvislosti s problematikou religiozity, ačkoliv i tato oblast zkoumání má své dnes již klasické práce (viz např́klad Roof 1999). V českých podmínkách se takto vymezenému tématu zatím nikdo systematicky nevěnoval, ačkoliv reflexe vlivu generační příslušnosti na religiozitu tvoří součást některých publikovaných textů, které se oblasti religiozity po roce 1989 sociologicky věnovaly (Hamplová 2000, 2001; Sak 2002; Spousta 2002). Žádný z nich však neučinil z problému generace ústřední bod analýzy, stejně jako žádný z nich s daty vztahujícími se ke generační příslušnosti nepracoval na základě hlubší teoretické reflexe.

Stat', kterou předkládáme, nemá ambici tento úkol beze zbytku naplnit. Její cíl je daleko skromnější: nabídnout některé předběžné závěry z dostupných empirických kvantitativních dat a naznačit směr, kterým by se další - obsáhlejší a systematičtější - sociologické studium

Sociální studia. Fakulta sociálních studií Masarykovy univerzity, 4/2010. S. 37-61. ISSN 1214-813X. Tato stat’ vznikla s podporou grantu GAČR GP403/09/P375 „Sekularizace v sociologické perspektivě“. Sběr dat, na nichž je tato analýza založena, byl financován projektem GAČR 403/08/0999 Hodnotové proměny v ČR 1991-2008 v evropském kontextu. 
mohlo v budoucnu ubírat. Domníváme se, že dané téma si zaslouží pozornost zejména ze dvou důvodů: 1. Aktuální sociologická literatura dokládá, že jednoduchá sekularizační očekávání nárůstu míry sekularizace společnosti s každou novou př́íchozí generací nedochází svého naplnění (Collins-Mayo a Dandelion 2010). Dostupná data ukazují, že jsou to mnohdy právě mladší věkové kohorty, které si k religiozitě nejrůznějšího druhu (včetně té označované za „tradiční“ - viz Hervieu-Léger 1994) nacházejí pozitivní vztah. Generační zkušenost spíše než nezpochybnitelný lineární trend modernizace, doprovázený „,automatickou“ sekularizací - se tak zdá být relevantnějším vysvětlujícím faktorem. 2. Postupně se kumulující empirická data o religiozitě z pravidelně se opakujících mezinárodních šetření (EVS, ISSP) prímo vybízejí ke studiu jejích vývojových tendencí. Je tak možné již srovnávat nejen mezigeneračně, ale sledovat i pohyby uvnitř jednotlivých generací v rámci plynutí času.

\section{K sociologickému chápání generace}

Pojem generace bývá někdy chápán jako synonymum pojmu kohorta. Kohortou se přitom v sociálních vědách rozumí souhrn jedinců, kteří prožili stejnou demografickou událost v tomtéž časovém období (Ryder 1965: 844-845). Nejběžnějším př́ikladem je věková kohorta všech lidí narozených ve stejném roce. ${ }^{2}$ Generace se v tomto demografickém pohledu chápe jako soubor několika věkových kohort.

Sociologický př́stup k chápání pojmu generace se historicky pojí se jménem Karla Mannheima (Mannheim 2007, Marada 2007a). Podle něj se společnost vyznačuje neustálým a plynulým nastupováním nových generací, které vždy participují pouze na časově omezeném úseku dějinného procesu a skrze něž dochází ke kontinuální transmisi kulturních statků. $\mathrm{V}$ jeho sociologii generací hrají klíčovou úlohu pojmy generační zasazení, generační souvislost a generační jednota.

Př́slušností ke stejnému ročníku narození je jedinec zasazen do života společnosti spolu s množstvím dalších lidí. Biologický základ je však jen vnějším rámcem vytváření generace. Společné generační zasazení v sociálním prostoru vzniká „teprve z toho plynoucí možností participovat na stejných událostech, životních obsazích apod., a ještě více možností činit tak ze stejného způsobu vrstvení vědomí“ (Mannheim 2007: 26). Generační souvislost se zakládá na př́buzném zasazení jedinců stejné generace v sociálním prostoru. Nezbytnou podmínkou jejího vzniku je participace na společných osudech historicko-sociální jednotky. Uvnitř jedné generační souvislosti pak může vznikat více generačních jednot, pokud různé skupiny zpracovávají prožitky různým způsobem.

Generace $\mathrm{v}$ tomto pojetí není pouze (náhodným) seskupením jedinců narozených ve stejné době, ale subjektem výrazně ovlivněným historickým a kulturním kontextem doby, kdy její př́íslušníci prožívali své formativní období. Mannheim (2007: 26) zdůrazňuje, že „pro jednu a tutéž ,zkušenost' a její relevanci a formování je takř́íkajíc rozhodující, zažije-li ji jedinec, který ji zpracuje jako zásadní dojem mládí, anebo někdo, kdo ji zpracuje jako

2 Jak upozorňuje Katrňák (2009: 56), kohorta nemusí být definována jen skrze rok narození, ba dokonce nutně ne ani skrze časový údaj. 
,pozdní zážitek““. Tato dominance raných dojmů je určující i v prŕípadě, kdy je celý další život snahou tyto rané dojmy negovat. ${ }^{3}$

Roof (2009: 623) konstatuje, že faktory ovlivňujícími generační identitu mohou být traumatické zážitky typu ekonomické krize, atentátu na významného politického činitele, války či prŕrodní katastrofy. Důležité je jejich silné emocionální zabarvení. Formativní událost ale nemusí být jen traumatická, ale i triumfální, jako např́klad pád Berlínské zdi (Giesen 2007: 72). Příslušná zkušenost má klíčový význam pro osoby, které ji absorbovaly v období vstupu do dospělosti, kdy je formována jejich kolektivní generační identita (Marada 2007b). Roof (2009: 622) uvádí, že lidé často v odpovědích na otázku po situacích, které významně ovlivnily jejich život, zmiňovali události, které se staly v době jejich teenagerství a těsně po dvacátém roce života.

S tím, jak jedinec stárne, se jeho identita usazuje - a platí to i pro kolektivní identitu generací. Konkrétními sociálními a kulturními událostmi a změnami v historii jsou generace ovlivněny nestejně. Touto rozdílnou percepcí událostí a změn se mezi generacemi vytvářejí rozdíly ve vyznávaných hodnotách a postojích, které si s sebou př́slušníci generace nesou životem. ${ }^{4}$ Stř́́dání generací tak představuje základní mechanismus, skrze který probíhá v populaci sociální změna (Dillon 2007).

\section{Socializace a náboženská víra}

Při formování identity jedince hraje podstatnou roli období primární socializace. Obsahům, které jsou internalizovány $\mathrm{v}$ raném věku, zůstává jedinec $\mathrm{v}$ průběhu svého života do značné míry věrný. Podstatnou měrou ovlivňují např́klad i jeho sklon $\mathrm{k}$ identifikaci $\mathrm{s}$ náboženskou vírou. Velký vliv má obvykle výchova $\mathrm{v}$ rodině, a to zejména $\mathrm{v}$ počátečním období socializace. Některé studie ale ukazují, že vliv rodičů přetrvává i v dalším průběhu života jedince. Ovlivnění míry religiozity přitom může být vzájemné (Sherkat 2003: 156).

Míra úspěchu v předání náboženské víry z rodičů na děti závisí na mnoha faktorech. Patř́i k nim např́íklad „,intenzita“ náboženského přesvědčení rodičů či skutečnost, zda oba dva vyznávají stejnou víru. Sňatek mezi lidmi odlišné víry nejenže snižuje pravděpodobnost přenosu víry na dítě, ale i toho, že oba rodičové zůstanou svému vyznání věrni (Voas 2003 podle Guest 2009: 661). Pozitivní statistický vliv konzistence náboženského chování rodičů a jejich kladných postojů $\mathrm{k}$ náboženství na přenos náboženské víry na děti potvrdili Bader a Desmond (2006). Jiné výzkumy ukázaly vliv prarodičů (zejména babiček) na religiozitu

3 Dillon (2007) ilustruje propojení věku, generace a historických podmínek na datech z longitudinálního výzkumu provedeného v Kalifornii. Data byla sbírána v rozmezí šedesáti let na vzorku respondentů, jehož třetina byla narozena v letech 1920-21 a dvě třetiny v letech 1928-29. I přes relativní věkovou blízkost se jedná o dvě skupiny s odlišnými zkušenostmi, což se projevilo mj. na proměnách jejich religiozity $\mathrm{v}$ průběhu života.

4 Rané období života je klíčové např́iklad i podle Ingleharta (1977), jehož koncept post-materialistické revoluce je postaven na předpokladu, že mezi současnou socioekonomickou úrovní a hodnotovými preferencemi jedince není přímý vztah. Hodnotový systém se formuje především během primární socializace individua, takže pro tvorbu hodnotových preferencí je rozhodující socioekonomická úroveň právě v této fázi života. 
svých vnuků a vnuček, ačkoli nižší než př́mý vliv rodičů (Bengtson a kol. 2009), a vzájemné posilování tohoto vlivu, pokud jsou prarodiče i rodiče silně věřící (Copen a Silverstein 2007). Generace narozené do společnosti v období náboženského oživení mohou také zpětně ovlivňovat religiozitu generace svých stárnoucích rodičů (Sherkat 2003: 157).

Výzkumy však zároveň ukazují, že přenos víry z rodičů na děti v současnosti slábne. Mladší generace již necítí takovou povinnost předat svou víru dětem, jako tomu bylo u generací starších. Tento trend je zřejmý zejména $\mathrm{v}$ západní Evropě. $\mathrm{V}$ šetření provedeném $\mathrm{v}$ roce 2006 ve Velké Británii bylo zjištěno, že pokud jsou oba z rodičů věřící, dítě má přibližně $50 \%$ pravděpodobnost, že si osvojí jejich víru. $V$ prípadě, že je věrící pouze jeden rodič, šance se snižují na 25\% (Crockett a Voas 2006: 577-578). Právě krize přenosu náboženské víry mezi generacemi je podle autorů pravděpodobnou príčinou postupující sekularizace společnosti. Nenacházejí přitom náznaky, že by tento trend mohl být zmírňován v důsledku efektu životního cyklu, který se projevuje nárůstem religiozity ve stáŕí.

Krize mezigeneračního přenosu je nejhlubší krizí, která může nějakou instituci či světonázor postihnout, nebot' ohrožuje její samotnou existenci (Hervieu-Léger 1998b, Sabe 2007). Na druhou stranu transmise hodnot a vzorců chování není nikdy dokonalá. Mezi generacemi vzniká vždy určitý konflikt. Hervieu-Léger hovoří o krizi transmise náboženských obsahů a identit jako o charakteristickém rysu modernity. Podle ní dochází k rozvolňování vazby jedince na určitý náboženský systém, do něhož byl dřive narozen, v němž byl socializován a který skrze své rodiče přijímal. Náboženská složka osobní identity již není něčím děděným, ale stává se stále více otázkou individuální volby. U rodičů mizí smysl pro povinnost předat dětem svou víru a celkově pak i smysl pro přináležení k náboženské komunitě. ${ }^{5}$

Při zkoumání proměny hodnot či postojů u generací musíme rozlišit mezi několika vlivy (Cavalli 2004, Katrňák 2009): 1) efekt věku (životního cyklu), který poukazuje na vliv samotného faktu vývoje jedince $\mathrm{v}$ souvislosti se životními fázemi, kterými prochází; 2) efekt doby, jenž značí vliv aktuální historické situace v době sběru dat; a 3) efekt generace, zdůrazňující vliv historických podmínek a událostí, které se odehrály během formativní fáze životního cyklu jedince. V praxi se tyto tři efekty pochopitelně mísí, a proto je obtížné (ne však zcela nemožné) je při analýze dat rozlišit.

Jak se vlivy věku, doby a generace promítají do vývoje indikátorů religiozity? Crockett a Voas (2006) reflektují efekty generace a doby na pokles religiozity. Konstatují, že v populaci dochází $\mathrm{k}$ poklesu religiozity, když 1) jedna či více generací vyroste $\mathrm{v}$ dospělé, kteří jsou méně nábožensky založeni, než jedinci $\mathrm{v}$ generacích předchozích (efekt generace); 2) jsou všechny generace postiženy úbytkem $v$ důsledku událostí v určitém období, např́iklad za druhé světové války či v 60. letech (efekt doby). Tyto dva vlivy se mohou navzájem umocňovat. Efekt věku může podle Crocketta a Voase pokles religiozity v populaci naopak zpomalovat či dokonce vyrovnávat, a to v př́ípadě, že platí hypotéza, že starší lidé jsou více nábožensky založení. Ve stárnoucích populacích (jako je tomu u populací většiny evropských států) by se pak zvyšoval podíl religióznějších obyvatel.

5 Daný trend demonstruje na datech ukazujících klesající počty křtů dětí do jednoho roku života a rostoucí počty křtů dospělých ve Francii (Hervieu-Léger 1998a). 


\section{Náboženská víra za komunistického režimu}

Jelikož se naše analýza odvíjí od zdůraznění vlivu historické zkušenosti jednotlivých generací na jejich náboženskou identitu, je vhodné se alespoň stručně zastavit u základního faktoru, který formoval zkušenost současných generací žijících v české společnosti - éry komunistického režimu. Českou zkušenost přitom budeme reflektovat v širším kontextu vývoje v regionu tzv. východního bloku.

Generačního rozměru problematiky si všímá Zrinščak (2004). Bez časové perspektivy podle něj není možné dostatečně porozumět sociálním změnám, které se udály během období komunistického režimu, a jejich vlivu na jednotlivé generace. Nová generace, nositelka sociální změny, s sebou nese proměny hodnot a postojů, a tedy i proměny religiozity a náboženské identity svých př́slušníků. Tento proces je přirozený, může však být násilně ovlivněn, jako v př́ípadě nastolení totalitního režimu. Tyto režimy mají silný dopad na formování generací, nebot' mají sklon zasahovat do generační identity nově příchozích generací, a to skrze intenzivní indoktrinaci a vynucené členství v masových organizacích. Nemohou se totiž spoléhat na tradiční způsoby transmise hodnot, nebot' ty reflektují hodnoty a postoje předchozího společenského a politického řádu. Prioritou se přitom stávají nejmladší generace, které jsou nejsnadněji ovlivnitelné (srovnej Cavalli 2004).

Tato snaha komunistických režimů střední a východní Evropy se výrazně projevila na náboženské socializaci generací narozených po 2 . světové válce. Totalitní systém si kladl nárok na celého člověka, snažil se získat vliv nad všemi sférami jeho života a vytvořit z něj nového, socialistického člověka. Náboženství - symbol starého řádu -, které si ze své povahy taktéž nárokuje celého člověka, bylo proto pro komunistickou ideologii jedním z hlavních soupeřu. Přestože se komunistickým režimům náboženství nepodařilo ze života lidí zcela vykořenit, dokázaly jej prakticky úplně vytlačit z veřejné sféry.

Strategie komunistického režimu pro nahrazení náboženského světonázoru vědeckým marxismem v podmínkách Československa sestávala z několika rovin. Klíčovou roli při implementaci oficiální ideologie hrál vzdělávací systém. Proto brzy došlo ke zrušení církevního i řádového školství, které bylo ideologicky nevyhovující. Výuka náboženství byla omezena na prostředí státních škol, ${ }^{6}$ redukována a kontrolována. Jak uvádí Hamplová (2001: 298), do roku 1952 byla výuka náboženství součástí školní výchovy, pravidla však byla rychle změněna. Účast na hodinách byla učiněna dobrovolnou a škola rodiče od přihlášení dětí do náboženství odrazovala. Již v polovině 50 . let tak na náboženství chodila méně než polovina dětí. Rapidní pokles se zastavil někdy na konci 70 . let na $5 \%$ dětí. Jistý přesun výuky do soukromí sice nastal, jednalo se však o menšinovou záležitost. Dětem byly ve škole vštěpovány socialistické hodnoty a antiklerikální interpretace dějin. Důležitý nástroj pro nahrazení tradičních věr a hodnot představovala popularizace vědy. Kromě snahy o rozšíření vědeckých poznatků mezi širokou veřejností zde byl zřejmý ideologický záměr (srovnej Wohlrab-Sahr, Schmidt-Lux a Karstein 2008).

Komunistický stát byl aktivní i v oblasti volného času. Četné spolky a organizace (Orel, Junák či Skaut) byly zakázány a jejich „socialistické“ náhrady se staly součástí přebudovávání společnosti. Na počátku roku 1950 byl schválen nový zákon o rodině, který ustanovil

6 Výjimkou bylo později krátké období na konci 60. let, kdy se náboženství přesunulo na fary. 
povinný občanský sňatek a církvím odebral zodpovědnost za vedení matrik. Světské rituály vykonávané státem postupně nahrazovaly rituály náboženské nejen v oblasti sňatků, ale i pohřbů a křtů. Mezi lety 1970 a 1988 poklesly počty církevních křtů z $59 \%$ na 26,3 \%, svateb z $35 \%$ na $11,1 \%$ a pohřbů z $66,9 \%$ na $37,8 \%$ (Hamplová 2001: 300).

$\mathrm{Na}$ úrovni výchovy $\mathrm{v}$ rodině můžeme pozorovat zřejmé oslabení přenosu náboženské víry na děti a celkově úbytek náboženské socializace $\mathrm{v}$ rodinách. To může souviset $\mathrm{s}$ diskriminací a perzekucí věřících i s proměnou role ženy v socialistické společnosti, zejména s nárůstem zaměstnanosti žen a podporou jeslí a mateřských škol. Mezi lidmi narozenými do roku 1931 bylo v některém z vyznání vychováno $92 \%$ populace, zatímco u osob narozených po roce 1976 již jen $23 \%$ (dle ISSP 1999 Hamplová 2001, viz tabulku 1).

Tabulka 1: Odpovědi na otázku: „V jakém vyznání nebo náboženství jste byl vychováván?“ (\%)

\begin{tabular}{|l|c|c|c|c|c|}
\hline \multirow{2}{*}{$\begin{array}{l}\text { Ročníky } \\
\text { narození }\end{array}$} & \multicolumn{5}{|c|}{ Náboženská výchova } \\
\cline { 2 - 6 } & Římskokatolická & Evangelická & Husitská & Ostatní & Žádná \\
\hline Do 1931 & 72,7 & 9,4 & 8,6 & 1,4 & 7,9 \\
\hline $1932-36$ & 76,3 & 2,6 & 11,8 & - & 9,2 \\
\hline $1937-41$ & 70,7 & 4,9 & 8,5 & 4,9 & 11,0 \\
\hline $1942-46$ & 70,5 & 1,8 & 5,4 & 1,8 & 20,5 \\
\hline $1947-51$ & 59,0 & - & 4,3 & 1,7 & 35,0 \\
\hline $1952-56$ & 54,5 & 2,5 & - & 0,8 & 42,1 \\
\hline $1957-61$ & 51,8 & 4,5 & 1,8 & - & 42,0 \\
\hline $1962-66$ & 41,1 & 2,2 & - & 2,2 & 54,4 \\
\hline $1967-71$ & 48,1 & - & - & 2,6 & 49,4 \\
\hline $1972-76$ & 29,7 & 2,7 & - & - & 67,6 \\
\hline $1977+$ & 20,0 & 3,0 & - & - & 77,0 \\
\hline
\end{tabular}

Zdroj: Hamplová (2001: 299) dle ISSP 1999.

Absence náboženské socializace se ukazuje jako klíčový aspekt. Jak jsme již uvedli dříve, výchova dítěte má podle výzkumů velký vliv na pozdější tendenci jedince identifikovat se s náboženstvím. Jak podotýká Hamplová (2001: 298), velká míra „,dědičnosti“ náboženské víry a prŕslušnosti k církvi je typická právě pro tradiční křest’anství velkých lidových církví. Potlačení náboženské výchovy tak je pravděpodobně jedním z faktorů, které ovlivnily pokles praktikované religiozity a náboženského vyznání.

Fiala (2007: 40) zdůrazňuje, že v případě Československa neplatí obecná periodizace komunistických režimů, kdy po roce 1953, respektive 1956, můžeme vidět zřetelné zmírnění represí. Na konci 50. let stále probíhaly procesy s duchovními a ještě začátkem 60 . let byla řada katolických kněží i laiků vězněna. Určitý předěl u nás nastal až v polovině 60 . let. Období kolem roku 1968 a tzv. Pražského jara bylo dobou dočasného zmírnění represí. Sedmdesátá léta se pak nesla ve znamení „normalizace“ poměrů a opětovného upevňování pozic komunistického režimu.

Náboženská obroda, pozorovaná ve většině zemí stř̌ední a východní Evropy v 80. letech, bývá někdy interpretována jako důkaz nesprávnosti klasických sekularizačních teorií. Tomka (1998a) ji datuje již od roku 1978, kdy byl papežem zvolen polský kněz Karol Wojtyla. Tento 
fakt měl obrovský vliv na polskou společnost, do jisté míry však ovlivnil i ostatní komunistické země a změnil také pohled Vatikánu na politickou situaci v nich. Ačkoli v české společnosti došlo $\mathrm{k}$ určitému nárůstu zájmu o náboženství, nikdy nedosáhl míry zaznamenané v jiných zemích regionu (Nešpor 2004). Tomka (1999) dodává, že 80. léta byla také obdobím proměny demografické struktury stoupenců církví. Církev už se neopírá o starší a méně vzdělané venkovské obyvatelstvo, ale o mladší a vzdělanější obyvatelstvo z měst, které je nositelem náboženské obrody.

Tomka (1998b: 243-244) rozeznává v industrializovaných zemích střední Evropy tři generace podle míry a typu jejich religiozity: starou generaci, narozenou před 2. světovou válkou; střední generaci, narozenou během války a od konce války do roku 1972; a generaci mladých, narozených po roce 1972. Nejstarší generace byla ještě nábožensky socializována, a vykazuje tak relativně vysokou míru náboženské identifikace. Střední generace je vykořeněnou generací s vysokou mírou individualismu, odcizení a „od-křest’anštění“, která odmítá církevní instituce a její př́padná religiozita se většinou realizuje mimo jejich hranice. Př́islušníci mladé generace odmítají „prázdnou“ religiozitu svých rodičů a jsou-li věřící, jsou více aktivní a častěji se hlásí $\mathrm{k}$ některé $\mathrm{z}$ tradičních či nových církví. I přes určitý nárůst religiozity u mladších lidí v porovnání s předešlou generací však podle Tomky nelze ve střední Evropě hovořit o výrazném náboženském oživení. Převážná část mladé generace je nevěrííí. Vyrostla bez náboženské socializace a navíc byla vystavena proticírkevnímu tlaku komunistické ideologie.

Jedním z typických rysů religiozity postkomunistických zemí se tak stal nelineární vývoj náboženských věr a praktik, kdy nedochází k pouhému postupnému poklesu; vývoj je nepravidelný. Tomka (1998b) v tomto kontextu nabádá k opatrnosti při interpretaci a př́padné predikci vývoje religiozity v budoucnu. Ten v sobě totiž zahrnuje dva protichůdné trendy: mírný nárůst religiozity ve všech věkových skupinách a zároveň nahrazování religióznějších starších věkových kohort mladšími. Věková struktura náboženské populace ovšem indikuje do budoucna spíše celkový trend oslabování náboženství (alespoň toho tradičního).

\section{Základní výzkumné otázky}

Pojem generace chápeme $\mathrm{v}$ této studii $\mathrm{v}$ jeho širším sociologickém smyslu. Historické a sociální podmínky $\mathrm{v}$ době formativního období jednotlivých generací tak nahlížíme jako významné pro podobu i sílu religiozity konkrétních generací v průběhu jejich života. $\mathrm{Na}$ tomto základě a se znalostí kontextu vývoje české společnosti v průběhu 20. století jsme v její populaci vymezili několik generací. Za hlavní časové body napomáhající identifikovat jednotlivé generace jsme zvolili roky 1945 a 1969. U respondentů narozených před rokem 1945 bylo ještě z velké části náboženství součástí jejich primární socializace - at' už v rodinách, nebo ve školách. S nástupem komunistického režimu byl v Československu zahájen aktivní boj proti náboženství. Všechny kohorty socializované po roce 1948 byly od raného dětství vystaveny ateizační a protináboženské kampani. Nejvíce pak toto působení zasáhlo kohorty socializované v 50. a na počátku 60 . let, kdy byla jeho síla nejvýraznější. Podle tohoto kritéria jsme se snažili rozdělit kohorty do generací tak, aby přibližně odpovídaly proměně podmínek praktikování náboženství a jeho transmise. Výběrový soubor jsme nicméně 
nerozdělili pouze do tři skupin, nýbrž do šesti, abychom byli citlivější k případným rozdílům uprostřed tří širokých generací (,předválečné“, „totalitní"“ a „,normalizační“).

Základní výzkumné otázky naší studie zní: Jakou podobu má v současnosti religiozita ${ }^{8}$ obyvatel České republiky při mezigeneračním srovnání? Odpovidají př́padné rozdíly $v$ religiozitě odlišným podmínkám socializace jednotlivých generací? Jak se proměňovala religiozita české populace $v$ uplynulých dvaceti letech uvnitř jednotlivých generací a v mezigeneračním srovnání? Předpokládáme přitom, že religiozita obyvatel České republiky a její vývoj po roce 1989 bude odrážet rozdílnou generační příslušnost dotazovaných v důsledku jejich odlišné (primární) socializace ve vztahu k náboženství. ${ }^{9}$

Nejvyšší míru religiozity očekáváme u generací narozených před rokem 1945, které by současně měly v demokratických podmínkách po roce 1989 vykazovat největší stabilitu, nebot' byly nejdůkladněji nábožensky socializovány. U generací narozených mezi lety 1945 a 1969 naopak předpokládáme míru religiozity výrazně nižší, a zejména u kohort socializovaných v 50. letech i udržování této nízké míry po roce 1989. Taktéž u nejmladších generací očekáváme nízkou míru religiozity, která by ovšem po roce 1989 měla narůstat, nebot' jejich sekulárnost neprripisujeme v takové míře protináboženské socializaci (jako u generace jejich rodičů), ale spíše ne-náboženské socializaci. Předpokládáme proto, že rozvoj „náboženského trhu“ po pádu komunistického režimu v nich mohl aktivovat potřebu náboženské seberealizace a duchovního hledání. Kromě religiozity samotné nás zajímají i názory na důležitost náboženské transmise, kde očekáváme trend postupného poklesu její důležitosti v pohledu dotazovaných, a to zejména u nejmladších a středních generací.

Pro analýzu jsme použili empirická kvantitativní data z Evropské studie hodnot (EVS) za Českou republiku ze trrí vln šetření realizovaných v letech 1991, 1999 a 2008, nebot' tento projekt nabízí vhodné (a různé) indikátory religiozity a umožňuje sledovat její vývoj v čase (blíže k tomuto výzkumu viz editorial tohoto čísla). Data byla zpracována s pomocí statistického software SPSS.

\section{Náboženská socializace}

Období primární socializace má klíčový vliv na pozdější identifikaci jedince s náboženstvím. Tradiční religiozita je úzce vázána na mezigenerační přenos $\mathrm{v}$ rodině. $\mathrm{V}$ datech EVS máme při zkoumání tématu náboženské socializace $\mathrm{k}$ dispozici několik indikátorů. Nacházíme otázky na důležitost pěstovat v dětech náboženství, ${ }^{10}$ na to, zda byli respondenti

7 Použili jsme tak jiné rozdělení než Lužný a Navrátilová (2001) či Spousta (1999, 2002). Blíže viz dále v textu.

8 Jsme si plně vědomi faktu, že religiozitu nelze zužovat pouze na tradiční křest'anskou (církevní) religiozitu. S ohledem na kontext české společnosti a zejména otázky dostupné v dotaznících EVS však v naší studii budeme vycházet z takto zúženého vymezení.

$9 \quad \mathrm{~K}$ jednotlivým indikátorům viz dále $\mathrm{v}$ textu.

10 Otázka: „Zde je seznam vlastností, jež mohou být v dětech doma pěstovány. Které z nich považujete za obzvlášt' dưležité? Prosím vyberte nejvýše 5: slušnost, samostatnost, pracovitost, odpovědnost, představivost, ohleduplnost a snášenlivost, spořivost a šetrnost, odhodláni a vytrvalost, náboženská víra, nesobeckost, poslušnost." 
vychováni v náboženském duchu, ${ }^{11}$ zda a jak často navštěvovali bohoslužbu ve věku 12 let ${ }^{12}$ a zda je podle nich důležitý obřad křtu při narození dítěte. ${ }^{13}$

První indikátor nám ukazuje, nakolik respondenti vnímají náboženskou víru jako důležitý vklad, jejž by měli dát dětem do života. V tabulce 2 vidíme, kolik jich zařadilo tuto položku mezi pět nejdůležitějších vlastností, jež by měly být předány. Důležitost náboženské výchovy poklesla z počátečních $10 \%$ v roce 1991 na $6,5 \%$ v roce 1999 , aby se posléze v roce 2008 vrátila mírně nad 10,5\%. Mírný propad v roce 1999 se projevil u všech generací, s výjimkou generace 1970-1980. Největší nárůst tohoto postoje zaznamenala generace narozená v letech 1957-1969 a nejčastěji jej zastávaly nejstarší věkové generace.

Tabulka 2: Podíl respondentư, kteří považují za obzvlášt duீležité pěstovat v dětech doma náboženství.

\begin{tabular}{|c|c|c|c|c|c|c|c|}
\hline \multirow[b]{2}{*}{ generace } & \multicolumn{2}{|c|}{1991} & \multicolumn{2}{|c|}{1999} & \multicolumn{2}{|c|}{2008} & \multirow{2}{*}{$\begin{array}{c}\text { rozdíl } \\
\text { 1991-2008 (v \%) }\end{array}$} \\
\hline & $\%$ & $\mathrm{~N}$ & $\%$ & $N$ & $\%$ & $N$ & \\
\hline $1981-1990$ & - & - & - & - & $6,8 \%$ & 26 & - \\
\hline $1970-1980$ & $5,0 \%$ & 7 & $6,7 \%$ & 25 & $9,3 \%$ & 27 & $+4,3$ \\
\hline 1957-1969 & $4,7 \%$ & 24 & $3,5 \%$ & 15 & $13,6 \%$ & 51 & $+8,9$ \\
\hline $1945-1956$ & $5,8 \%$ & 29 & $3,6 \%$ & 15 & $7,6 \%$ & 27 & $+1,8$ \\
\hline 1932-1944 & $11,0 \%$ & 51 & $7,8 \%$ & 30 & $16,3 \%$ & 40 & $+5,3$ \\
\hline $1931-$ & $19,8 \%$ & 97 & $16,2 \%$ & 38 & $16,5 \%$ & 14 & $-3,3$ \\
\hline celkem & $9,9 \%$ & 208 & $6,6 \%$ & 125 & $10,7 \%$ & 185 & $+0,8$ \\
\hline
\end{tabular}

Zdroj: EVS 1991, EVS 1999, EVS 2008.

Srovnejme nyní důležitost předání náboženské víry s indikátorem ukazujícím, zda byl respondent vychován v náboženské víře (na datech pro rok 1991). ${ }^{14}$ Graf 1 ukazuje, že tři čtvrtiny respondentů generace narozené před rokem 1932 byly vychovány v náboženském duchu. Pouze pětina této generace však považovala předání víry za něco obzvláště důležitého. Tak je tomu i u dalších generací, přičemž u ročníků narozených po roce 1944 se procento hlásající důležitost předání víry ustálilo kolem 5-6\%. Ačkoli tak byly zejména starší generace často vychovávány $\mathrm{k}$ náboženství, $\mathrm{v}$ současnosti nepovažují jeho předávání v porovnání $\mathrm{s}$ dalšími

11 Otázka: „Byl/a jste vychován/a v náboženském duchu? - Ano; ne.“ Otázka byla položena pouze $\mathrm{v}$ roce 1991.

12 Otázka: „Když nepočitáte svatby, pohřby a křtiny, jak často jste navštěvoval(a) bohoslužby, když Vám bylo 12 let? - Častěji než jednou týdně; jednou týdně; jednou za měsíc; o Vánocích/o Velikonocích; o jiných konkrétních náboženských svátcich; jednou za rok; méně často; nikdy, v podstatě nikdy. “ Pro účely naší analýzy byly sloučeny varianty 1 až 2 (alespoň jedenkrát týdně) a 4 až 6 (alespoň jedenkrát za rok).

13 Otázka: „Myslite si Vy osobně, že je di̊ležité provádět církevni obřady při přiležitosti následujicích událostí? - Narození: Ano; ne. “

14 Otázka: „Byl/a jste vychován/a v náboženském duchu?“ s variantami odpovědí „ano“, „ne“. Tato otázka byla zařazena do výzkumu v roce 1991, v dalších vlnách již byla bohužel vyřazena. Proto provedeme srovnání na datech z roku 1991. 
hodnotami za něco obzvláště důležitého. ${ }^{15}$ Tento poznatek naznačuje, že i v relativně dobře nábožensky socializovaných generacích se ztrácí smysl pro předání víry, je narušena transmise. Je ovšem třeba si uvědomit, že ani socializace těchto generací nebyla bezproblémová. Antiklerikální nálady První republiky jako vyústění již dříve přítomných tendencí zproblematizovaly zejména katolickou identitu jako „samozřejmost“. Na druhou stranu je nutné zdůraznit, že námi užitý indikátor důležitosti náboženství je specifický. Respondent vybírá 5 z 11 položek, které považuje za nejdůležitější pěstovat ve svých dětech. Je tedy pravděpodobné, že pokud se do tohoto výběru dostane také náboženská víra, značí to vysokou angažovanost respondenta $\mathrm{v}$ této oblasti. Kdybychom se zeptali jinak, např́íklad zda respondent považuje za důležité předat svému dítěti náboženskou víru (se 4 variantami od určitě ano po určitě ne), pravděpodobně bychom dospěli k vyšším hodnotám deklarované transmise.

Graf 1: Srovnání podílu respondentů/respondentek vychovaných v náboženském duchu a považujicích za dưležité pěstovat $v$ dětech doma náboženství podle generací.

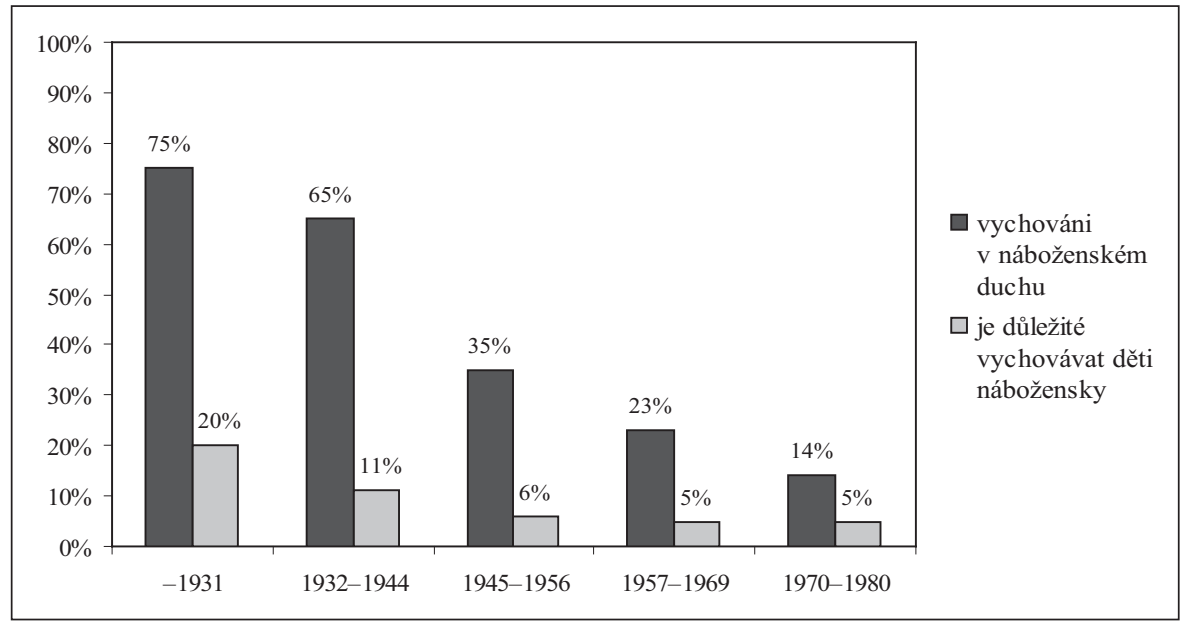

Zdroj: EVS 1991.

Dalším indikátorem je otázka na návštěvnost bohoslužeb ve věku 12 let, která bývá do výzkumu zařazována pravidelně. Analyzovali jsme data z roku 2008 a srovnávali účast dotazovaných ve věku 12 let a v současnosti. A tím sledovali, zda respondenti zůstali či nezůstali věrni tomu, $\mathrm{k}$ čemu byli v dětství doma vedeni. Předpokládáme totiž, že dvanáctileté dítě chodí do kostela zpravidla se svými rodiči, prípadně prarodiči, a pod jejich vlivem.

Na uvedených datech (tabulka 3) můžeme sledovat velký propad mezi generací 19321944 a 1945-1956. U starší z těchto dvou generací navštěvovalo ve věku 12 let 1 krát či vícekrát měsíčně bohoslužbu kolem $45 \%$ osob, u mladší to bylo jen $24 \%$. V průběhu 50 . let tak

15 Ve všech třech vlnách respondenti nejčastěji zmiňovali jako nejdůležitější hodnoty slušnost, pracovitost, samostatnost a ohleduplnost. 
dochází k výraznému oslabení náboženské transmise, což koresponduje s vývojem dalších proměnných týkajících se náboženské socializace.

Tabulka 3: Participace na bohoslužbách ve 12 letech a v současnosti - srovnání tří vybraných kategorií odpovědi v roce 2008. (Dalšími kategoriemi jsou „alespoň 1x ročně“ a „méně často“.)

\begin{tabular}{|l|c|c|c|c|c|c|}
\hline \multirow{2}{*}{ generace } & \multicolumn{2}{|c|}{ alespoň 1x týdně } & \multicolumn{2}{c|}{ alespoň 1x měsíčně } & \multicolumn{2}{c|}{ nikdy, téměř nikdy } \\
\cline { 2 - 7 } & ve 12 letech & nyní & ve 12 letech & nyní & ve 12 letech & Nyní \\
\hline $1981-1990$ & $5,8 \%$ & $4,0 \%$ & $1,9 \%$ & $1,3 \%$ & $65,0 \%$ & $65,7 \%$ \\
\hline $1970-1980$ & $9,3 \%$ & $5,3 \%$ & $2,7 \%$ & $3,0 \%$ & $67,4 \%$ & $64,1 \%$ \\
\hline $1957-1969$ & $13,3 \%$ & $8,1 \%$ & $3,0 \%$ & $3,2 \%$ & $58,7 \%$ & $63,1 \%$ \\
\hline $1945-1956$ & $19,5 \%$ & $8,5 \%$ & $4,8 \%$ & $3,4 \%$ & $47,6 \%$ & $52,7 \%$ \\
\hline $1932-1944$ & $35,7 \%$ & $16,2 \%$ & $9,7 \%$ & $7,1 \%$ & $29,0 \%$ & $48,1 \%$ \\
\hline $1931-$ & $39,0 \%$ & $18,2 \%$ & $6,1 \%$ & $7,8 \%$ & $29,3 \%$ & $44,2 \%$ \\
\hline celkem & $16,6 \%$ & $8,4 \%$ & $4,1 \%$ & $3,5 \%$ & $53,8 \%$ & $58,7 \%$ \\
\hline
\end{tabular}

Zdroj: EVS 2008.

Poslední proměnnou, kterou budeme zkoumat v souvislosti s náboženskou socializací, je vůle rodičů své děti po narození pokřtít. Přitom jsme si vědomi faktu, že provedení křtu ještě nemusí znamenat, že bude dítě rodiči ve víře také vychováno a že křest může být někdy vykonán spíše na přání prarodičů než rodičů. Tím, co nás zde ovšem primárně zajímá, je vědomí závazku křtu narozeného dítěte jakožto součásti socializace.

Tabulka 4: Podíl respondentư, kteři považují za důležité provedení církevního obřadu při príležitosti narození dítěte.

\begin{tabular}{|l|c|c|c|c|c|c|c|}
\hline \multirow{2}{*}{ generace } & \multicolumn{2}{|c|}{1991} & \multicolumn{2}{c|}{1999} & \multicolumn{2}{c|}{2008} & \multirow{2}{*}{ rozdíl } \\
\cline { 2 - 7 } & $\%$ & $\mathrm{~N}$ & $\%$ & $\mathrm{~N}$ & $\%$ & $\mathrm{~N}$ & $1991-2008$ ( $\%$ ) \\
\hline $1981-1990$ & - & - & - & - & $22,9 \%$ & 75 & - \\
\hline $1970-1980$ & $51,2 \%$ & 64 & $33,9 \%$ & 117 & $25,5 \%$ & 65 & $-25,7$ \\
\hline $1957-1969$ & $37,7 \%$ & 173 & $33,8 \%$ & 135 & $32,2 \%$ & 101 & $-3,9$ \\
\hline $1945-1956$ & $39,4 \%$ & 185 & $40,0 \%$ & 150 & $43,5 \%$ & 136 & $+4,1$ \\
\hline $1932-1944$ & $54,8 \%$ & 234 & $51,5 \%$ & 187 & $53,6 \%$ & 120 & $-1,2$ \\
\hline $1931-$ & $64,7 \%$ & 290 & $54,6 \%$ & 118 & $57,5 \%$ & 42 & $-7,2$ \\
\hline celkem & $49,1 \%$ & 946 & $41,7 \%$ & 728 & $35,8 \%$ & 539 & $-13,3$ \\
\hline
\end{tabular}

Zdroj: EVS 1991, EVS 1999, EVS 2008.

Jak tabulka 4 ukazuje, celkově počet lidí přikládajících křtu důležitost v průběhu let 1991 až 2008 výrazně poklesl (ze 49\% na 36 \%), což lze vysvětlit především nahrazováním starších religióznějších generací generacemi mladšími. V rámci jednotlivých generací totiž dochází pouze $\mathrm{k}$ malým posunům, s výjimkou nejstarší generace, kde došlo k mírnému poklesu o 7\%, a generace 1970-1980, kde došlo k rapidnímu poklesu z 51 na 26 \% 
respondentů přikládajících křtu důležitost. ${ }^{16}$ Ochota pokřtít dítě stoupá se stáŕím generace (s výjimkou vysoké hodnoty u generace 1970-1980 v roce 1991). Vzhledem k faktu, že rození dětí se týká spíše mladých generací (tedy v současnosti těch narozených po roce 1969), můžeme očekávat, že procento pokřtěné populace společně s odchodem nejstarších generací výrazně poklesne, nebot' děti bude křtít přibližně čtvrtina až třetina rodičů. ${ }^{17}$

Data o náboženské socializaci v souhrnu dokládají, že klesá význam křtu, a to v důsledku postupné výměny starších, křtu více nakloněných generací generacemi mladšími. Uvnitř generací ke změnám postoje příliš nedochází. Smysl pěstovat v dětech náboženskou víru zůstává naopak na přibližně stejné hodnotě, s mírným nárůstem u většiny generací. Může to být způsobeno tím, že v éře komunistického režimu u lidí natolik poklesla důležitost tohoto aspektu výchovy, že už v roce 1991 byla na velmi nízké úrovni. V roce 1999 sice hodnota indikátoru poklesla, ale v roce 2008 se opět vrátila na původní úroveň.

Zmíněné dva indikátory jsou ukazateli pasivní a aktivní religiozity. Pokřtít dítě může znamenat přihlásit se $\mathrm{k}$ určité tradici, dopřát dítěti to, co kdysi zažil rodič sám, či prostě jen vyslyšet prosby prarodičů. Pěstovat v dítěti víru je již však velký závazek, srovnatelný s pravidelnou participací na bohoslužbách, čemuž by odpovídalo podobné procento populace navštěvující alespoň 1 krát týdně bohoslužby. Koeficient asociace mezi důležitostí pěstovat $\mathrm{v}$ dítěti náboženství a návštěvou bohoslužeb tento předpoklad potvrzuje - hodnota Cramerova V byla v letech 1991 a 1999 0,57, což značí silnou souvislost, v roce 2008 o něco poklesla na 0,49 .

Zřejmý zlom u všech sledovaných proměnných pozorujeme mezi generacemi narozenými před rokem 1945 a od roku 1945 dále. Generace narozené před rokem 1945 byly vychovány během období První republiky či 2. světové války, a to z velké míry v náboženském duchu. Jejich př́slušníci chodili v mládí relativně často do kostela a velmi pravděpodobně byli pokřtěni. Náboženská socializace později narozených generací byla o poznání slabší. Překvapivé však je, že jak generace narozených před rokem 1945, tak generace mladší deklarují malou vůli předat náboženskou víru, v níž byly vychovány, dalším generacím. Ačkoli se v roce 1991 tři čtvrtiny osob z nejstarší generace označily za vychované v náboženském duchu, pouhá pětina viděla jako důležité vychovávat děti nábožensky. Na datech z roku 2008 také vidíme, že ani nejstarší generace si svou v mládí praktikovanou víru plně neuchovaly zatímco ve věku 12 let chodilo pravidelně týdně do kostela 39\% (respektive 36\%) generace narozené před rokem 1932 (respektive generace 1932-1944), dnes je to pouze 18\% (respektive $16 \%$ ). I u nich dochází k oslabování náboženské praxe, což by nám mohlo vysvětlovat, proč pro ně otázka přenosu náboženské víry na potomky není tak důležitá, jak bychom očekávali.

16 Toto číslo je př̀kvapivě vysoké. Vzhledem $\mathrm{k}$ menšímu počtu respondentů spadajících v roce 1991 do této generace může být odchylka vysvětlena výběrovou chybou.

17 Ve výzkumu Detradicionalizace a individualizace náboženství v České republice v roce 2006 bylo zjištěno, že v současnosti je pokřtěno více než 60 \% Čechů a Češek (naprostá většina jich byla pokřtěna v dětství), pouze $33 \%$ však považuje za důležité pokřtít své děti (tedy podobné procento, jaké přináší výzkum EVS v roce 2008; Václavík 2010: 205). 


\section{Příslušnost k náboženskému vyznání a náboženská participace}

Tradičními indikátory užívanými pro zkoumání religiozity jsou otázky ohledně přihlášení se $\mathrm{k}$ náboženskému vyznání ${ }^{18}$ a participace na bohoslužbách. Zatímco přihlášení se $\mathrm{k}$ některému náboženskému vyznání může být pouze formální záležitostí, pravidelná účast na bohoslužbách naznačuje aktivní př́istup. Deklarované náboženské vyznání navíc nemusí vždy být synonymem pro př́ślušnosti $\mathrm{k}$ církvi, ${ }^{19}$ zatímco návštěvnost bohoslužeb je spjata s některou z církví, byt' ani zde nemusí být souvislost absolutní. Jak uvádí Spousta (2002), přihlášení se k náboženskému vyznání může být ovlivňováno subjektivními pocity respondenta v době dotazování či aktuálním mediálním obrazem, který církve mají. Ani kdybychom však použili „objektivní“ data, jako jsou např́klad počty křtů, nemohou nám podat o mnoho přesnější obrázek už jen z prostého důvodu, že křest je nevratný, a z církve tedy není možno $\mathrm{v}$ tomto smyslu vystoupit. $\mathrm{V}$ převážné většině prrípadů jsou jedinci křtěni na základě rozhodnutí svých rodičů, nikoli svého, a byli-li pokřtěni, ještě to neznamená, že je rodiče ve viře také vychovali (Václavíková-Helšusová a Václavík 2006).

Václavík a Václavíková-Helšusová (2006: 175) rozlišují mezi členstvím formálním, kdy se př́slušnost př́liš nepromítá do života jedince, a žitým, kdy jedinec aktivně participuje na životě svého náboženského společenství. Indikátor náboženského vyznání nám ukazuje spíše míru tohoto formálního členství, nebot' z něho nezjistíme míru angažovanosti jedince v náboženském společenství či hloubku jeho přesvědčení ve věroučných otázkách vybrané konfese. Co nám však ukázat může, je ochota jedince přihlásit se k určité kulturní a historické tradici (Hamplová 2001).

Tabulka 5: Současné náboženské vyznání podle generací (podíl respondentů, kteří se hlásí k náboženskému vyznání).

\begin{tabular}{|c|c|c|c|c|c|c|c|}
\hline \multirow{2}{*}{ generace } & \multicolumn{2}{|c|}{1991} & \multicolumn{2}{|c|}{1999} & \multicolumn{2}{|c|}{2008} & \multirow{2}{*}{$\begin{array}{c}\text { rozdíl } \\
1991-2008 \text { (v \%) }\end{array}$} \\
\hline & $\%$ & $\mathrm{~N}$ & $\%$ & $N$ & $\%$ & $N$ & \\
\hline $1981-1990$ & - & - & - & - & $12,5 \%$ & 47 & - \\
\hline $1970-1980$ & $14,3 \%$ & 20 & $21,0 \%$ & 78 & $18,8 \%$ & 57 & $+4,5$ \\
\hline 1957-1969 & $17,7 \%$ & 91 & $22,2 \%$ & 97 & $22,7 \%$ & 85 & $+5,0$ \\
\hline $1945-1956$ & $29,9 \%$ & 149 & $30,1 \%$ & 123 & $32,7 \%$ & 116 & $+2,8$ \\
\hline 1932-1944 & $54,2 \%$ & 250 & $49,1 \%$ & 188 & $46,7 \%$ & 115 & $-7,5$ \\
\hline $1931-$ & $69,7 \%$ & 340 & $57,1 \%$ & 133 & $56,0 \%$ & 47 & $-13,7$ \\
\hline celkem & $40,4 \%$ & 850 & $33,3 \%$ & 627 & $26,9 \%$ & 467 & $-13,5$ \\
\hline
\end{tabular}

Zdroj: EVS 1991, EVS 1999, EVS 2008.

18 Otázka: „Hlásite se k nějakému náboženskému vyznání? Ano; ne. “

19 Ve výzkumu religiozity Aufbruch v zemích východní a střední Evropy byla otázka na vyznání respondenta formulována jako otázka na př́islušnost k církvi. Oproti výsledkům výzkumů konaných v podobném období vykázal tento indikátor pokles o přibližně $20 \%$. Z toho autoři vyvozují, že v dotazovaných vzbuzují pojmy „,církev“ a „,náboženské vyznání، odlišné konotace (Václavíková-Helšusová a Václavík 2006). 
S vědomím výše zmíněných limitů se nyní podívejme na vývoj hodnot těchto dvou indikátorů ve výzkumu EVS. Na datech ze tř́ vln (tabulka 5) vidíme zřejmý pokles podílu lidí hlásících se k náboženskému vyznání. Tento trend jasně naznačovala data z roku 1999 a poslední vlna výzkumu jej jen potvrdila. ${ }^{20}$ Když se podíváme na vývoj u jednotlivých generací, získáme o situaci plastičtější představu. U dvou generací narozených v rozmezí let 1957-1980 zaznamenáváme ve sledovaném období mírný nárůst, střední generace 1945-1956 vykazuje relativně stabilní podíl vyznávajících a u dvou nejstarších generací dochází k poklesu podílu vyznávajících. Zatímco v roce 1991 byl rozdíl mezi generací nejstarší a nejmladší $55 \%$, dnes jsou si tyto dvě generace blíže (rozdíl činí $37 \%$ vzhledem ke generaci 1970-1980, respektive 43,5 \% vzhledem ke generaci 1981-1990). Změny přitom zaznamenáváme zejména mezi roky 1991 a 1999, poté už zůstává podíl přibližně stejný. Přesto však celkový podíl vyznávajících klesl, nebot’ nejstarší generace odchází a z nově nastupující generace se obecně hlásí k vyznání jen malý podíl (např́ílad pouze 12,5\% prríslušníků generace narozené v 80 . letech).

Předpoklad, že starší, a tedy častěji nábožensky socializované generace si budou udržovat oproti generacím mladším podstatně vyšší míru přihlášení se k náboženskému vyznání, se potvrdil. Mezi generacemi jsou znatelné rozdíly, největší v roce 1991, ale stále výrazné i v roce 2008, přičemž největší rozdíl nacházíme mezi generacemi 1932-1944 a 1945-1956 (ve třech vlnách výzkumu se tyto generace liší postupně o $24 \%, 19 \%$, respektive $14 \%$ ).

Ačkoli by se dalo očekávat, že více nábožensky socializované generace budou vykazovat v průběhu let 1991 až 2008 menší výkyvy v náboženském vyznání, ukazuje se, že u těchto ročníků došlo ke značnému úbytku. Nejvyšší pokles u dvou nejstarších ročníků nastal mezi lety 1991 a 1999.

Pokles míry př́slušnosti české populace $\mathrm{k}$ náboženskému vyznání v 90 . letech může být vysvětlen tím, že období revolučního nadšení přimělo mnoho respondentů $\mathrm{k}$ vyjádření své prŕslušnosti $\mathrm{k}$ církvi, aniž by byli silně věřícími či praktikujícími. Toto přihlášení mohlo často vyjadřovat spíše podporu dlouhá léta perzekuované církvi a radost $\mathrm{z}$ možnosti svobodně se přihlásit k církvi svých rodičů či prarodičů. Vyšší míra náboženského vyznání pravděpodobně souvisela i s relativně větši prestiží katolické církve v důsledku její role v období kolem listopadu 1989.

Tyto faktory se mohly projevit nejvíce právě u těch, kteří si $\mathrm{k}$ církvi vytvořili nějaký vztah už v mládí a nebyli tolik vystaveni protináboženské propagandě komunistického režimu. V průběhu 90. let však prestiž katolické církve postupně klesala (Mišovič 1999) a opadla porevoluční atmosféra. Pokud by se míra vyznávajících v rámci generací ustálila, jak to vidíme na vývoji mezi léty 1999 a 2008, můžeme říci, že spolu s tím, jak budou

20 Krom výzkumu EVS se touto otázkou zabývaly také další výzkumy - např́iklad Sčítání lidu 1991 a 2001, výzkum Světové biblické společnosti (1991) a International Social Survey Programme (ISSP 1995 a 1999). K náboženskému vyznání se podle nich hlásilo 44\% (Sčítání 1991), 51\% (BIBL 1991), 47,5 \% (ISSP 1995), 55,3 \% (ISSP 1999) a 32 \% respondentů (Sčítání 2001). (Pro srovnání těchto výzkumů viz Václavíková-Helšusová a Václavík 2006.) Výsledky se od sebe velmi liší zejména v roce 1999. Procenta zjištěná výzkumem EVS se nejvíce blíží výsledkům ze Sčítání lidu. 
nejstarší generace postupně odcházet a budou je nahrazovat generace mladší a méně religiózní, bude celkový počet vyznávajících ubývat, a to navzdory mírnému nárůstu u mladších generací.

Tabulka 6: Participace na bohoslužbách (uvedeno procento respondentů, kteří navštěvují bohoslužbu alespoň jedenkrát týdně).

\begin{tabular}{|l|c|c|c|c|c|c|c|}
\hline \multirow{2}{*}{ generace } & \multicolumn{2}{|c|}{1991} & \multicolumn{2}{c|}{1999} & \multicolumn{2}{c|}{2008} & rozdíl \\
\cline { 2 - 7 } & $\%$ & $\mathrm{~N}$ & $\%$ & $\mathrm{~N}$ & $\%$ & $\mathrm{~N}$ & $1991-2008$ (v \%) \\
\hline $1981-1990$ & - & - & - & - & $4,0 \%$ & 15 & - \\
\hline $1970-1980$ & $5,8 \%$ & 8 & $4,1 \%$ & 15 & $5,3 \%$ & 16 & $-0,5$ \\
\hline $1957-1969$ & $3,9 \%$ & 20 & $3,0 \%$ & 13 & $8,1 \%$ & 30 & $+4,2$ \\
\hline $1945-1956$ & $5,0 \%$ & 25 & $4,1 \%$ & 17 & $8,4 \%$ & 30 & $+3,4$ \\
\hline $1932-1944$ & $8,4 \%$ & 39 & $10,4 \%$ & 40 & $16,2 \%$ & 39 & $+7,8$ \\
\hline $1931-$ & $19,3 \%$ & 94 & $18,3 \%$ & 42 & $18,2 \%$ & 14 & $-1,1$ \\
\hline celkem & $8,8 \%$ & 186 & $7,0 \%$ & 131 & $8,4 \%$ & 144 & $-0,4$ \\
\hline
\end{tabular}

Zdroj: EVS 1991, EVS 1999, EVS 2008.

Podívejme se nyní na náboženskou participaci dotazovaných (viz tabulku 6). ${ }^{21}$ Podíl těch, kteří navštěvují pravidelně alespoň 1 krát týdně bohoslužby, je o poznání nižší než podíl vyznávajících. Pravidelná návštěva bohoslužby 1 krát týdně, zpravidla v neděli, je jedním z požadavků katolické církve. U ostatních církví, například Českobratrské církve evangelické či Československé církve husitské, takto př́isná pravidla nenalezneme, přesto také tyto církve zpravidla slouží každou neděli bohoslužby. Interval 1x týdně navíc vyjadřuje relativně velkou míru angažovanosti a aktivní postoj. Základní věcí, kterou můžeme pozorovat, je stabilní míra participace ve všech třech vlnách, pohybující se mezi 7 a $9 \%$. To potvrzuje, že participace na bohoslužbách měří spíše aktivní než formální členství - údaj z roku 1991 se narozdíl od deklarace náboženského vyznání výrazně neliší od ostatních let. Generace narozené před rokem 1945 navštěvují pravidelně bohoslužby výrazně častěji než generace mladší.

Pokud se zaměříme na stav v roce 2008, zřetelný odstup v míře pravidelné týdenní i měsíční participace existuje mezi dvěma nejstaršími generacemi a generací socializovanou od konce 40. do začátku 60. let. Tento odstup se však výrazně projevil právě až v roce 2008, v předchozích vlnách výzkumu byl menší. Důvodem je relativně velký nárůst participace u generace 1932-1944. Lidé této generace byli v roce 1991 ještě pracující, v roce 2008 však již byli všichni v důchodu, a mohli se tedy vzhledem k nárůstu volného času přiklonit k větší angažovanosti ve věcech náboženské víry, ve které byli v mládí vychováni. Zajímavé je, že zatímco participace této generace vzrostla $\mathrm{v}$ daném období o téměř $8 \%$, poklesl v ní současně o $7,5 \%$ podíl vyznávajících.

21 Otázka: „Když nepočitáte svatby, pohřby nebo křtiny, jak asi často nyní navštěvujete bohoslužby?“ 
Graf 2 znázorňuje návštěvnost bohoslužeb u jednotlivých generací v roce 2008 . Dozvídáme se tak, že ze tří nejmladších generací nechodí nikdy do kostela kolem $65 \%$ respondentů, dalších 10-15\% pak méně často než $1 \mathrm{x}$ ročně. Poměrně častým jevem je také návštěva bohoslužby $1 \mathrm{x}$ ročně, což může znamenat například účast na vánoční půlnoční mši.

Graf 2: Návštěvnost bohoslužeb podle generací v roce 2008.

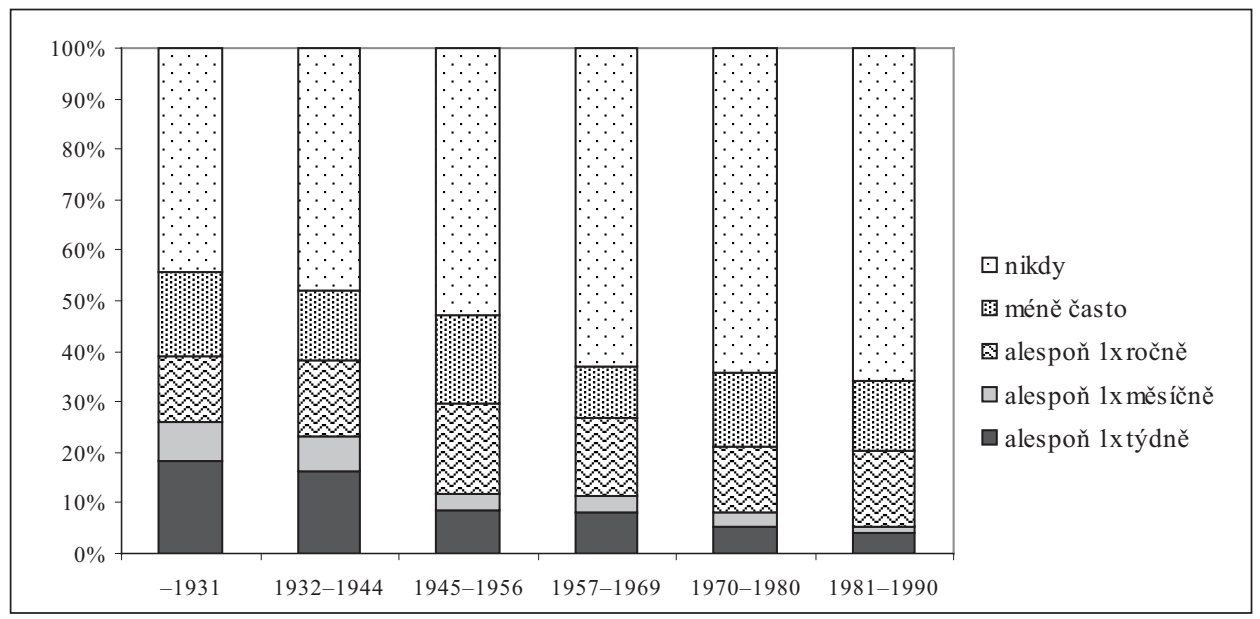

Zdroj: EVS 2008.

Z výše zmíněného je zřejmé, že generace narozené před rokem 1945 vykazují podstatně vyšší míru tradiční religiozity než generace mladší, a to jak z hlediska přihlášení se k víré, tak z hlediska participace. Oproti očekávání se u dvou nejstarších generací ukázal nejvyšší pokles v přihlášení se $\mathrm{k}$ vyznání, participace se ale naopak zvýšila. A zatímco v oblasti vyznání se k sobě jednotlivé generace ve sledovaném období přibližily (nebot' míra vyznávajících u dvou nejstarších generací klesala, zatímco u mladších mírně rostla), rozdíly mezi participací jednotlivých generací se spíše prohloubily. Zlomová čára je nicméně v obou př́padech opět nastavena mezi dvěma nejstaršími generacemi a těmi narozenými po roce 1945 .

\section{Proměny náboženské víry}

Skutečnost, že se mnoho obyvatel České republiky nehlásí k náboženskému vyznání, ještě nemusí znamenat, že jsou Češi „neveřícím“ či „,ateistickým“ národem. I trendy v západní Evropě naznačují, že náboženská př́slušnost (,belonging“) a náboženské přesvědčení („,believing“) se nutně nemusejí překrývat (např́íklad Davie 1994). Na druhou stranu stále platí, že převážnou většinu lidí, označujících se za „věříci“", tvoří respondenti hlásící se k některému (u nás nejčastěji katolickému) vyznání. V roce 1991 tvořili v české populaci lidé bez vyznání $15 \%$ všech veřících, o 8 let později se jejich podíl zdvojnásobil na necelých $30 \%$ a v roce 2008 opět poklesl, a to na $18 \%$. 
Tabulka 7 ukazuje, že největší souvislost mezi vyznáním a sebedeklarací respondenta jako věřícího zaznamenáváme u nejstarších generací a nejmenší u generací nejmladších. ${ }^{22}$ V současné době se věřící lidé narození do roku 1956 v naprosté většině (kolem $90 \%$ ) hlásí k náboženskému vyznání, u mladších ročníků tvoří jejich podíl výrazně nižší procento (67 \% u generace 80 . let). Třetina nejmladší věřící generace tak není ztotožněna s žádným vyznáním. Sledujeme tak určitý generační posun - zatímco pro dříve narozené je vcelku samozřejmé spojovat svou víru s konkrétním vyznáním, pro mladší ročníky je tato samozřejmost narušena. To, že jsou věřícími, pro ně neznamená nutně patřit k nějakému vyznání. Postoje zejména nejmladší generace tak můžeme interpretovat jako „believing without belonging“ (Davie 1994).

Tabulka 7: Podíl respondentů hlásících se k náboženskému vyznání mezi věřícími a nevěřícími. ${ }^{23}$

\begin{tabular}{|c|c|c|c|c|c|c|c|}
\hline & \multicolumn{2}{|c|}{1991} & \multicolumn{2}{|c|}{1999} & \multicolumn{2}{|c|}{2008} \\
\hline & & $\%$ & $\mathrm{~N}$ & $\%$ & $\mathrm{~N}$ & $\%$ & $\mathrm{~N}$ \\
\hline \multirow{7}{*}{ věřící } & $1981-1990$ & - & - & - & - & $66,7 \%$ & 42 \\
\hline & 1970-1980 & $59,3 \%$ & 16 & $56,2 \%$ & 68 & $73,0 \%$ & 46 \\
\hline & 1957-1969 & $73,7 \%$ & 73 & $55,9 \%$ & 80 & $75,5 \%$ & 74 \\
\hline & $1945-1956$ & $78,8 \%$ & 104 & $68,2 \%$ & 101 & $89,9 \%$ & 98 \\
\hline & 1932-1944 & $88,1 \%$ & 200 & $81,3 \%$ & 157 & $91,2 \%$ & 103 \\
\hline & 1931- & $92,0 \%$ & 299 & $88,3 \%$ & 121 & - & - \\
\hline & celkem & $85,4 \%$ & 692 & $70,5 \%$ & 535 & $82,0 \%$ & 400 \\
\hline \multirow{7}{*}{ nevěřící } & $1981-1990$ & - & - & - & - & $1,0 \%$ & 2 \\
\hline & 1970-1980 & $0,0 \%$ & 0 & $2,5 \%$ & 5 & $1,3 \%$ & 2 \\
\hline & 1957-1969 & $3,3 \%$ & 11 & $3,0 \%$ & 7 & $3,1 \%$ & 6 \\
\hline & $1945-1956$ & $8,7 \%$ & 25 & $7,3 \%$ & 15 & $7,3 \%$ & 12 \\
\hline & 1932-1944 & $12,2 \%$ & 19 & $13,9 \%$ & 19 & $7,8 \%$ & 6 \\
\hline & 1931- & $16,8 \%$ & 18 & $9,4 \%$ & 5 & - & - \\
\hline & celkem & $7,5 \%$ & 73 & $5,9 \%$ & 51 & $4,0 \%$ & 33 \\
\hline
\end{tabular}

* Údaje pro generaci 1931-za rok 2008 nebyly do tabulky zahrnuty pro malý počet prípadů.

Zdroj: EVS 1991, EVS 1999, EVS 2008.

V rámci jednotlivých generací souvislost mezi vyznáním a vírou v rozmezí let 1991 a 2008 mírně narostla. V roce 2008 je tedy pravděpodobnější, že věřící bude respondent zároveň vyznávající. ${ }^{24}$ Vlivem nejmladší generace však celkový podíl vyznávajících mezi

22 Data z tabulky nám potvrzuje také korelační koeficient (Kendalovo tau-c) pro tyto dvě proměnné. Nejnižší hodnoty vykazuje koeficient u nejmladších generací a postupně roste až ke generaci 19321944, u které spolu přesvědčení a vyznání nejvíce koreluje. V roce 2008 se tak koeficient pohybuje od střední souvislosti $(0,40)$ u nejmladší generace po velmi silnou souvislost $(0,87)$ u generace 1932-1944.

23 Otázka po náboženském přesvědčení zahrnuje ještě možnost ,ateista“, jejíž hodnoty však v tabulce neuvádíme, nebot' prakticky všichni tito respondenti spadají do kategorie bez vyznání, a navíc je tato kategorie oproti ostatním dvěma velmi málo obsazená, proto toto porovnání nemá smysl.

24 Výraz „vyznávající“ zde užíváme ve smyslu „přináležející k určitému vyznání“, ve smyslu „belonging“. 
veřícími mírně poklesl. Nejmenší podíl věřících se přihlásil $\mathrm{k}$ vyznání v roce 1999. Tehdy oproti roku 1991 poklesla hodnota indikátoru vyznání, u indikátoru víry se naopak držela na stejné úrovni. V populaci bylo tehdy zaznamenáno $33,5 \%$ vyznávajících a $43 \%$ věřících. Tento rozdíl se nejvíce projevil u středních generací (1945-1969), kde došlo k poklesu vyznávajících mezi věřícími o 18 procentních bodů (respektive o 11 u mladší z generací). ${ }^{25}$

Žrejmý trend nacházíme mezi nevěřícími: zatímco v roce 1991 se 7,5\% nevěřících přihlásilo k vyznání, v roce 2008 to byla jen $4 \%$. Samotný rozdíl není př́liš velký, ale když se podíváme na distribuci odpovědí $\mathrm{v}$ rámci generací, vidíme, že $\mathrm{v}$ generacích narozených po roce 1956 je podíl vyznávajících mezi nevěřícími prakticky zanedbatelný, zatímco u starších generací tvoří podstatně vyšší procento. Mezi nejstaršími generacemi je tak nejvyšší podíl tzv. formálně vyznávajících (lidí, kteří se hlásí k vyznání, ale nepovažují se za věrící). Jak tyto generace postupně tvoří menší a menší podíl na celkové populaci (a zároveň i v rámci nich ubývá nevěřících vyznávajících), ubývá v populaci formálních či tzv. „vlažných“ stoupenců církve (jak o tom píši např́klad Spousta 1999 či Halík 2000). V mladších generacích se pak formální vyznávající prakticky nevyskytují.

Celkový počet věrících v populaci klesnul ze 43 \% v letech 1991 a 1999 na $31 \%$ v roce 2008 (viz tabulku 8). Ještě v roce 1999 to tedy vypadalo, že ačkoli klesá počet vyznávajících (ze 40,5\% na 33,5 \%), věřících lidí bude v populaci stále přibližně stejný podíl. Ačkoli je v současnosti věřících stále více než vyznávajících, rozdíl se zmenšil (31\% věřících oproti $27 \%$ vyznávajících). K mírnému nárůstu podílu věřících došlo u generací narozených po roce 1944, u starších naopak nastal pokles. Počet neveřících se stabilně pohyboval okolo poloviny populace, $\mathrm{v}$ rámci generací však došlo $\mathrm{k}$ výraznému poklesu počtu nevěrících $\mathrm{u}$ generací narozených v letech 1945 až 1980 (o 16-19 \%). Data naznačují, že se pravděpodobně presunuli do kategorie přesvědčených ateistů. Počet deklarovaných přesvědčených ateistů totiž ve sledovaném období výrazně vzrostl, a to z 5,5\% v roce 1991 na $19 \%$ v roce 2008 . Největší podíl na jejich nárůstu mají dvě nejmladší generace, narozené v 70. a v 80. letech, mezi kterými nalezneme v současnosti $22 \%$ deklarovaných přesvědčených ateistů. K nárůstu tohoto postoje však došlo ve všech generacích bez výjimky. V průběhu sledovaného období tak v populaci úměrně úbytku věŕících přibylo přesvědčených ateistů. Můžeme pouze spekulovat, zdali posun probíhá tak, že věřící se stávají nevěřícími a nevěřící se mění v ateisty. Lze však tvrdit, že deklarovaný ateismus získává v naší společnosti oproti 90 . letům mnohem silnější pozici.

25 Rozdíl mezi podílem věřících a vyznávajících v roce 1999 potvrzuje také korelační koeficient těchto dvou proměnných, nebot' jeho hodnota byla $v$ tomto roce nejnižší. Hodnota Cramerova V byla v roce 1991 0,78, v roce 1999 0,69 a v roce 2008 0,82, stále ovšem velmi silná. Výsledky jsou statisticky signifikantní $(0,000)$. 
Tabulka 8: Podíl věrících, nevěrících a ateistů v generacích.

\begin{tabular}{|c|c|c|c|c|c|c|c|}
\hline & \multicolumn{2}{|c|}{1991} & \multicolumn{2}{|c|}{1999} & \multicolumn{2}{|c|}{2008} & \multirow{2}{*}{$\begin{array}{c}\text { rozdíl } \\
\text { 1991-2008 (v \%) }\end{array}$} \\
\hline & $\%$ & $N$ & $\%$ & $N$ & $\%$ & $N$ & \\
\hline \multicolumn{8}{|l|}{ Věřící } \\
\hline $1981-1990$ & - & - & - & - & $17,8 \%$ & 64 & - \\
\hline $1970-1980$ & $21,6 \%$ & 27 & $34,2 \%$ & 121 & $23,1 \%$ & 64 & $+1,5$ \\
\hline 1957-1969 & $21,7 \%$ & 99 & $34,5 \%$ & 143 & $28,0 \%$ & 100 & $+6,3$ \\
\hline $1945-1956$ & $29,9 \%$ & 133 & $40,3 \%$ & 154 & $34,5 \%$ & 118 & $+4,6$ \\
\hline 1932-1944 & $55,4 \%$ & 227 & $55,3 \%$ & 199 & $50,9 \%$ & 115 & $-4,5$ \\
\hline 1931- & $71,3 \%$ & 326 & $62,2 \%$ & 138 & $55,8 \%$ & 43 & $-15,5$ \\
\hline celkem & $42,9 \%$ & 812 & $43,3 \%$ & 771 & $30,8 \%$ & 504 & $-12,1$ \\
\hline \multicolumn{8}{|l|}{ Nevěřící } \\
\hline $1981-1990$ & - & - & - & - & $59,9 \%$ & 215 & - \\
\hline 1970-1980 & $72,0 \%$ & 90 & $56,8 \%$ & 201 & $54,9 \%$ & 152 & $-17,1$ \\
\hline 1957-1969 & $74,0 \%$ & 338 & $57,1 \%$ & 237 & $54,9 \%$ & 196 & $-19,1$ \\
\hline $1945-1956$ & $64,5 \%$ & 287 & $53,9 \%$ & 206 & $48,2 \%$ & 165 & $-16,3$ \\
\hline 1932-1944 & $38,3 \%$ & 157 & $38,1 \%$ & 137 & $34,1 \%$ & 77 & $-4,2$ \\
\hline 1931- & $23,6 \%$ & 108 & $23,9 \%$ & 53 & $27,3 \%$ & 21 & $+3,7$ \\
\hline celkem & $51,7 \%$ & 980 & $48,5 \%$ & 865 & $50,4 \%$ & 826 & $-1,3$ \\
\hline \multicolumn{8}{|c|}{ Přesvědčený ateista } \\
\hline $1981-1990$ & - & - & - & - & $22,3 \%$ & 80 & - \\
\hline $1970-1980$ & $6,4 \%$ & 8 & $9,0 \%$ & 32 & $22,0 \%$ & 61 & $+15,6$ \\
\hline 1957-1969 & $4,4 \%$ & 20 & $8,4 \%$ & 35 & $17,1 \%$ & 61 & $+12,7$ \\
\hline $1945-1956$ & $5,6 \%$ & 25 & $5,8 \%$ & 22 & $17,3 \%$ & 59 & $+11,7$ \\
\hline $1932-1944$ & $6,3 \%$ & 26 & $6,7 \%$ & 24 & $15,0 \%$ & 34 & $+8,7$ \\
\hline 1931- & $5,0 \%$ & 23 & $14,0 \%$ & 31 & $16,9 \%$ & 13 & $+11,9$ \\
\hline celkem & $5,4 \%$ & 102 & $8,2 \%$ & 146 & $18,8 \%$ & 308 & $+13,4$ \\
\hline
\end{tabular}

Zdroj: EVS 1991, EVS 1999, EVS 2008.

To, že se člověk označí za věřícího, nám ještě neříká nic o tom, v co věří. Tradiční religiozita je v české společnosti spojena s představou Boha. Zaměřili jsme se tedy nejprve na víru v Boha jako takovou a poté na zastávanou představu Boha. V otázce na existenci Boha ${ }^{26}$ je opět vidět zřetelné odlišení víry podle věkových generací (viz tabulku 9). V první vlně výzkumu EVS se ukazuje rok 1945 jako výrazný předěl, kdy generace narozené po tomto roce věří v Boha výrazně méně než generace narozené dříve (vidíme rozdíl 24 \%). Zatímco si víra v Boha u starších generací v průběhu sledovaného období drží prakticky stejnou míru, u mladších ročníků dochází ke zřetelnému nárůstu, nejvíce u dvou středních generací (narozených 1945-1969), kde došlo ke zvýšení podílu věřících o 17, respektive 14 \%. Starší z těchto generací přesto v roce 1999 vykazovala nejnižší víru v Boha ze všech generací, avšak rozdíl oproti dvěma mladším generacím byl minimální. V současnosti platí, že čím mladší generace, tím méně věří v Boha. Zmenšily se však odstupy mezi generacemi

26 Otázka: „Věřite, že existuje Bůh?“ s variantami ano a ne. Respondenti, kteří na otázku neodpověděli, nebyli zahrnuti do výpočtu procent $\mathrm{v}$ tabulce. 
(zejména pokud si v roce 2008 odmyslíme nejstarší generaci, nebot’ ta má již velmi málo př́slušníků).

Tabulka 9: Víra v existenci Boha (podíl respondentů, kteří věří v Boha).

\begin{tabular}{|l|c|c|c|c|c|c|c|}
\hline \multirow{2}{*}{ generace } & \multicolumn{2}{|c|}{1991} & \multicolumn{2}{c|}{1999} & \multicolumn{2}{c|}{2008} & rozdíl \\
\cline { 2 - 7 } & $\%$ & $\mathrm{~N}$ & $\%$ & $\mathrm{~N}$ & $\%$ & $\mathrm{~N}$ & $1991-2008$ ( $\mathrm{\%} \%)$ \\
\hline $1981-1990$ & - & - & - & - & $21,2 \%$ & 66 & - \\
\hline $1970-1980$ & $21,6 \%$ & 25 & $32,6 \%$ & 105 & $30,3 \%$ & 74 & $+8,7$ \\
\hline $1957-1969$ & $19,1 \%$ & 86 & $33,1 \%$ & 126 & $32,9 \%$ & 98 & $+13,8$ \\
\hline $1945-1956$ & $22,7 \%$ & 99 & $30,8 \%$ & 107 & $39,9 \%$ & 119 & $+17,2$ \\
\hline $1932-1944$ & $46,4 \%$ & 186 & $48,9 \%$ & 159 & $44,9 \%$ & 89 & $-1,5$ \\
\hline $1931-$ & $64,4 \%$ & 277 & $58,6 \%$ & 116 & $64,7 \%$ & 44 & $+0,3$ \\
\hline celkem & $36,7 \%$ & 673 & $39,0 \%$ & 632 & $34,6 \%$ & 490 & $-2,1$ \\
\hline
\end{tabular}

Zdroj: EVS 1991, EVS 1999, EVS 2008.

Vidíme tedy, že v současnosti přibližně třetina české populace věří v Boha. Co však lidé chápou pojmem Bůh? V křest’anské tradici je Bůh chápán jako „osoba“, někteří lidé se však mohou přiklánět k méně ,„personifikovanému“ vymezení. Tabulka 10 zobrazuje podíl lidí, kteří věří v Boha jako osobu, $\mathrm{v}$ existenci ducha či životní síly a kteří nevěří v Boha $\mathrm{v}$ žádné podobě. $^{27}$

Zaměřme se nejprve na víru v „Boha jako osobu“. První, co nás zaujme, je velký propad u této varianty v roce 1999. Spousta (2001) jej vysvětluje změnou formulace odpovědi, kdy v roce 1991 zjišt'oval výzkum víru v „osobního Boha““. ${ }^{28}$ Vzhledem k datům z roku 2008, kdy byla použita stejná formulace jako v roce 1999, lze však toto vysvětlení těžko přijmout. Celkový propad z 12 \% na 6,5 \% se projevil ve všech generacích, nejvíce v nejstarší generaci, u generace 1957-1969 dosáhla víra v Boha jako osobu vůbec nejnižšího podílu 3,5 \%. V roce 2008 se však u všech generací podstatně zvýšil podíl této odpovědi (kromě generace 1970-1980). V celkovém součtu se tak víra v Boha jako osobu dostala přibližně na úroveň roku 1991.

27 Otázka: „Který z těchto výroků je nejbliže Vašemu přesvědčeni? Existuje Bůh jako osoba; existuje cosi jako duch nebo životní sila; skutečně nevím, co si mám myslet; skutečně si nemyslím, že existuje nějaký druh duchovní, božské nebo životní síly." V tabulce jsou uvedena procenta respondentů, kteří uvedli danou variantu odpovědi. Dopočet do $100 \%$ tvoř́i kategorie „skutečně nevím, co si mám myslet“", kterou jsme neuvedli v tabulce, protože není pro interpretaci natolik významná, podíl respondentů v ní se př́lliš nemění. $\mathrm{V}$ roce 1991 to bylo $27 \%$, v roce $199921 \%$ a v roce $200824 \%$ respondentů.

28 Zmíněné znění variant odpovědí je z dotazníku z roku 1999. V dotazníku EVS 1991 však byla jako první možnost použita formulace ,existuje osobni Bůh“. Jak upozorňuje Spousta (2001: 356), lidé mohli toto vyjádření chápat spíše ve smyslu ,patřící někomu“, tedy můj vlastní Bůh. Po změně formulace se proto podle něj k této variantě přiklonilo výrazně méně respondentů. Tato změna zůstala i v dotazníku pro rok 2008, kde byla navíc v dalších variantách odpovědi nahrazena slova životní síla slovy „vyšši moc“. 
Tabulka 10: Pojetí Boha (podíl respondentư, kłeři uvedli vybranou kategorii).

\begin{tabular}{|c|c|c|c|c|c|c|c|}
\hline & \multicolumn{2}{|c|}{1991} & \multicolumn{2}{|c|}{1999} & \multicolumn{2}{|c|}{2008} & \multirow{2}{*}{$\begin{array}{c}\text { rozdíl } \\
\text { 1991-2008 (v \%) }\end{array}$} \\
\hline & $\%$ & $\mathrm{~N}$ & $\%$ & $\mathrm{~N}$ & $\%$ & $\mathrm{~N}$ & \\
\hline \multicolumn{8}{|c|}{ Existuje Bůh jako osoba } \\
\hline $1981-1990$ & - & - & - & - & $5,4 \%$ & 19 & - \\
\hline 1970-1980 & $6,7 \%$ & 9 & $4,9 \%$ & 18 & $7,4 \%$ & 21 & $+0,7$ \\
\hline 1957-1969 & $6,7 \%$ & 32 & $3,5 \%$ & 15 & $10,5 \%$ & 34 & $+3,8$ \\
\hline $1945-1956$ & $6,6 \%$ & 31 & $4,5 \%$ & 18 & $11,3 \%$ & 37 & $+4,7$ \\
\hline $1932-1944$ & $14,4 \%$ & 65 & $10,1 \%$ & 38 & $20,0 \%$ & 42 & $+5,6$ \\
\hline 1931- & $23,3 \%$ & 107 & $13,1 \%$ & 29 & $27,4 \%$ & 23 & $+4,1$ \\
\hline celkem & $12,2 \%$ & 244 & $6,5 \%$ & 120 & $11,1 \%$ & 176 & $-1,1$ \\
\hline \multicolumn{8}{|c|}{ Existuje cosi jako duch nebo životní síla } \\
\hline $1981-1990$ & - & - & - & - & $23,7 \%$ & 84 & - \\
\hline 1970-1980 & $33,3 \%$ & 45 & $50,3 \%$ & 183 & $30,5 \%$ & 87 & $-2,8$ \\
\hline 1957-1969 & $38,3 \%$ & 182 & $47,5 \%$ & 201 & $28,0 \%$ & 91 & $-10,3$ \\
\hline $1945-1956$ & $37,0 \%$ & 175 & $55,0 \%$ & 220 & $30,2 \%$ & 99 & $-6,8$ \\
\hline $1932-1944$ & $40,2 \%$ & 181 & $48,9 \%$ & 185 & $31,9 \%$ & 67 & $-8,3$ \\
\hline $1931-$ & $36,1 \%$ & 166 & $45,5 \%$ & 101 & $27,4 \%$ & 23 & $-8,7$ \\
\hline celkem & $37,6 \%$ & 749 & $50,2 \%$ & 922 & $28,4 \%$ & 451 & $-9,2$ \\
\hline \multicolumn{8}{|c|}{ Skutečně si nemyslím, že existuje nějaký druh duchovní, božské nebo životní síly } \\
\hline $1981-1990$ & - & - & - & - & $42,1 \%$ & 149 & - \\
\hline 1970-1980 & $30,4 \%$ & 41 & $22,5 \%$ & 82 & $41,4 \%$ & 118 & $+11,0$ \\
\hline 1957-1969 & $28,0 \%$ & 133 & $25,1 \%$ & 106 & $37,8 \%$ & 123 & $+9,8$ \\
\hline $1945-1956$ & $30,0 \%$ & 142 & $23,3 \%$ & 93 & $32,6 \%$ & 107 & $+2,6$ \\
\hline 1932-1944 & $18,9 \%$ & 85 & $19,3 \%$ & 73 & $29,5 \%$ & 62 & $+10,6$ \\
\hline $1931-$ & $13,9 \%$ & 64 & $20,3 \%$ & 45 & $25,0 \%$ & 21 & $+11,1$ \\
\hline celkem & $23,3 \%$ & 465 & $22,3 \%$ & 409 & $36,6 \%$ & 580 & $+13,3$ \\
\hline
\end{tabular}

Zdroj: EVS 1991, EVS 1999, EVS 2008.

„Propad“ z roku 1999 lze jen obtížně interpretovat. Největší podíl lidí (celá polovina těch, kteří odpověděli) se v tomto roce ztotožnil s odpovědí, že existuje něco jako duch či životní síla, tedy s méně konkrétní a s křest’anstvím ne tak spojenou koncepcí. V roce 1999 se tato víra u všech generací pohybovala na konstantně vysoké úrovni (mezi 44,5 a 55 \%). Počet lidí, kteř́ v nic podobného nevěří, se držel stabilně mezi pětinou a čtvrtinou populace. Na konci 90. let mohla tato data naznačovat, že dochází k určitému odklonu od tradičního pojetí Boha směrem $\mathrm{k}$ méně tradiční spiritualitě založené na víře $\mathrm{v}$ existenci neurčité/neosobní síly či ducha. Nejnovější data ale tento trend nepotvrzují. O tom, zda se jednalo o problém vzorku, nebo zda šlo o změnu postojů (nebot' rozdíly jsou relativně velké), můžeme pouze spekulovat. Mezi lety 1991 a 2008 navíc výrazně stoupá podíl lidí nevěrících v žádné duchovní či božské síly, což koresponduje s dříve zmíněným nárůstem podílu respondentů deklarujících ateismus. $\mathrm{V}$ obou těchto kategoriích sledujeme nárůst postoje např́č všemi věkovými kategoriemi. Stále však platí, že čím mladší generace, tím větší procento nevěřících (respektive ateistů). 


\section{Závěr}

Máme-li shrnout výše prezentované poznatky a vztáhnout je k našim výchozím výzkumným otázkám, jsme nuceni konstatovat následující. Empirická data dokládají, že v obecné rovině platí nepřímá úměra mezi mírou tradiční religiozity (respektive její důležitosti v životě respondentů) a věkem. Nejstarší generace v roce 2008 vykazují prakticky u všech indikátorů tradiční religiozity nejvyšší hodnoty. Náš předpoklad, že tyto rozdíly je možné vztáhnout k podmínkám socializace jednotlivých generací v souvislosti s nástupem protinábožensky orientovaného politického režimu v roce 1948, podporují dvě důležité skutečnosti.

Za prvé, největší předěl se nachází mezi generacemi narozenými před rokem 1945 a po roce 1945, což naznačuje účinnost protináboženského tažení poúnorového režimu (viz zejména indikátory víry $\mathrm{v}$ Boha, sebeidentifikace jakožto věřícího, přihlášení se $\mathrm{k}$ náboženskému vyznání či návštěvnosti bohoslužeb ve 12 letech). Za druhé, vývoj religiozity ve sledovaných dimenzích v období mezi lety 1991-2008, které kromě jiného přineslo náboženskou svobodu a pluralitu, demonstruje mírný nárůst religiozity u středních generací (zejména v př́padě víry v Boha) a současně mírný pokles u nejstarších generací.

$\mathrm{Z}$ hlediska trendů uplynulých dvaceti let patři $\mathrm{k}$ těm nejvýznamnějším tendence $\mathrm{k}$ poklesu (přihlášení se $\mathrm{k}$ náboženskému vyznání, sebeidentifikace jako věřící osoby, důležitost křtu dítěte) či stagnaci (víra v existenci Boha, respektive Boha jako osoby; participace na bohoslužbách) celkově nízké míry tradiční religiozity, což lze přičítat především postupné generační proměně. Uvnitř tohoto procesu však můžeme zaznamenat jisté přibližování se generací a „tlumeni“" generačních rozdílů, a to zejména v důsledku zvyšující se míry religiozity u středních generací (narozeni v letech 1945-69). Současně můžeme pozorovat určité „vyjasňování“ a „usazování“ náboženské (respektive ne-náboženské) identity české populace, dokladem čehož je nárůst podílu osob, které se deklarují jako přesvědčení ateisté a které odmítají jakékoliv pojetí boha.

Naše studie pochopitelně nemohla pokrýt všechny důležité pohyby a souvislosti a pracovala $\mathrm{s}$ celou řadou redukcí (v rozčlenění generací, výběru indikátorů apod.). Přesto se domníváme, že v souladu s na úvod deklarovaným záměrem naznačila cestu, která se při sociologickém výzkumu současné české religiozity jeví být plodnou a dalšího rozpracování hodnou. Jsme si současně vědomi toho, že kvantitativní data (a to i tehdy, je-li jich k dispozici dostatek) nám dovolují rozkrýt vlivy generačního zasazení jedinců na jejich religiozitu a světonázorovou identifikaci jen v omezené míre. Neumožňují např́klad dostatečně reflektovat Mannheimem pojednaný fakt existence více generačních jednot uvnitř jedné generační souvislosti. Proto by nedílnou součást sociologického zájmu o tuto problematiku měly představovat i kvalitativně zaměřené studie, které by např́klad skrze biografická vyprávění dokázaly s většími nuancemi zachytit proces utváření a přetváření (ne)náboženských identit v české populaci (viz u nás např́klad Spalová 2004, jinde v postkomunistickém regionu pak např́íklad Bögre 2001 či Wohlrab-Sahr, Karstein a Schmidt-Lux 2009). 


\section{Literatura:}

BADER, Christopher D. ; DESMOND, Scott A. Do as I Say and as I Do : The Effects of Consistent Parentel Beliefs and Behaviors Upon Religious Transmission. Sociology of Religion, 2006, roč. 67, č. 3, s. 313 - 329. ISSN 1069-4404.

BENGTSON, Vern L. ; COPEN, Casey E. ; PUTNEY, Norella M. ; SILVERSTEIN, Merril. A Longitudinal Study of the Intergenerational Transmission of Religion. International Sociology, 2009, roč. 24, č. 3, s. 325 - 345. ISSN 0268-5809.

BÖGRE, Zsuzsanna. The hidden paths of religious identity-two life stories. In BOROWIK, I., TOMKA, M. (eds.) Religion and social changing in post-communist Europe. Kraków : Nomos, 2001, s. 93 - 111. ISBN 83-88508-26-1.

CAVALLI, Alessandro. Generations and Value Orientations. Social Compass, 2004, roč. 51, č. 2, s. 155 - 168. ISSN 0037-7686.

COLlinS-MAYO, Sylvia ; DANDELION, Pink. (eds.) Religion and Youth. Farnham : Ashgate, 2010. 273 s. ISBN 978-0-7546-6764-3.

COPEN, Casey E. ; SILVERSTEIN, Merril. Transmission of Religious Beliefs across Generations : Do Grandparents Matter? Journal of Comparative Family Studies, 2007, roč. 38, č. 4, s. 497 - 510. ISSN 0047-2328.

CROCKETT, Alasdair ; VOAS, David. Generations of Decline : Religious Change in 20th-Century Britain. Journal for the Scientific Study of Religion, 2006, roč. 45, č. 4, s. 567 - 584. ISSN 0021-8294.

DAVIE, Grace. Religion in Britain since 1945 : Believing without belonging. Oxford : Blackwell, 1994. 240 s. ISBN 0-6311-8444-9.

DILLON, Michele. Age, Generation, and Cohort in American Religion and Spirituality. In BECKFORD, J.A., DEMERATH N.J. (eds.) The SAGE Handbook of the Sociology of Religion. London : SAGE Publications. 2007, s. 526 - 544. ISBN 1-4129-1195-8.

FIALA, Petr. Laboratoř sekularizace. Náboženství a politika v ne-náboženské společnosti : český prípad. 1. vyd. Brno : Centrum pro studium demokracie a kultury, 2007. 183 s. ISBN 978-80-7325-141-3.

GIESEN, Bernard. V různém čase, v různém rytmu a s různou pamětí. Sociální studia, 2007, roč. 4, č. 1-2, s. 67 - 78. ISSN 1214-813X.

GUEST, Mathew. The Reproduction and Transmission of Religion. In CLARKE, P. B. (ed.) The Oxford Handbook of the Sociology of Religion. Oxford : Oxford University Press, 2009, s. $651-670$. ISBN 0-1992-7979-9.

HALÍK, Tomáš. Katolická církev v České republice po roce 1989. In Společnost v přerodu. Češi ve 20. století. Praha : Masarykův ústav AV ČR, 2000, s. 144 - 158. ISBN 80-86495-01-9.

HAMPLOVÁ, Dana. Šetření ISSP 1998 - Náboženství. Sociologický časopis, 2000, roč. 36, č. 4, s. 431 - 440. ISSN 0038-0288.

HAMPLOVÁ, Dana. Institucionalizované a neinstitucionalizované náboženství v českém poválečném vývoji. Soudobé dějiny, 2001, roč. 8, č. 2-3, s. 294 -311. ISSN 1210-7050.

HERVIEU-LÉGER, Danièle. Religion, Memory and Catholic Identity : Young People in France and the 'New Evangelization of Europe'. In FULTON, J., GEE, P. (eds.) Religion in Contemporary Europe. London: The Edwin Mellen Press, 1994, s. 125 - 138. ISBN 0-7734-9028-0.

HERVIEU-LÉGER, Danièle. The Figure of the Converted as Descriptive Figure of Religious Modernity : A Reflection Based on the File of Conversions to Catholicism in France. In LAERMANS, R., WILSON, B., BILLIET, J. (eds.) Secularization and Social Integration. Papers in Honor of Karel Dobbelaere. Leuven : Leuven University Press, 1998a, s. 277 - 286. ISBN 978-90-6186-932-0.

HERVIEU-LÉGER, Danièle. The Transmission and Formation of Socioreligious Identities in Modernity. An Analytical Essay on the Trajectories of Identification. International Sociology, 1998b, roč. 13, č. 2, s. $213-228$. ISSN 0268-5809. 
INGLEHART, Ronald. The Silent Revolution. Changing Values and political Styles Among Western Publics. Princeton : Princeton University Press, 1977. ISBN 0-6911-0038-1.

KATRŇÁK, Tomáš. Kohortní analýza jako alternativa panelového výzkumu. Data a výzkum - SDA Info, 2009, roč. 3, č. 1, s. 53 - 74. ISSN 1802-8152.

LUŽNÝ, Dušan ; NAVRÁTILOVÁ, Jolana. Náboženství a sekularizace v České republice. Sociální studia, 2001, č. $6, \quad$ s. $111-125$. ISSN 1214-813X.

MANNHEIM, Karl. Problém generací. Sociálni studia, 2007, roč. 4, č. 1-2, s. 11 - 44. ISSN 1214-813X.

MARADA, Radim. Karl Mannheim : Sociologie generací. In ŠUBRT, J. (ed.) Historická sociologie. 1. vyd. Plzeň : Aleš Čeněk, 2007a, s. 118 - 139. ISBN 978-80-7380-061-1.

MARADA, Radim. Pamět', trauma, generace. Sociální studia, 2007b, roč. 4, č. 1-2, s. 79 - 95. ISSN 1214-813X.

MIŠOVIČ, Jan. Czech Confidence in the Church in Comparison with Other Institutions. In BOROWIK, I. (eds.) Church-State Relations in Central and Eastern Europe. Kraków : Nomos, 1999. ISBN 83-85527-88-5.

NEŠPOR, Zdeněk R. Ústřední vývojové trendy současné české religiozity. In NEŠPOR, Z.R. (ed.) Jaká víra? Současná česká religiozita/spiritualita v pohledu kvalitativní sociologie náboženství. 1. vyd. Praha : Sociologický ústav AV ČR, 2004, s. 21 - 37. ISBN 80-7330-061-3.

ROOF, Wade C. Spiritual Marketplace. Baby Boomers and the Remaking of American Religion. Princeton : Princeton University Press, 1999, 384 s. ISBN 0-6910-8996-5.

ROOF, Wade C. Generations and Religion. In CLARKE, P. B. (ed.) The Oxford Handbook of the Sociology of Religion. Oxford : Oxford University Press, 2009, s. 616 - 634. ISBN 0-1992-7979-9.

RYDER, Norman B. The Cohort as a Concept in the Study of Social Change. American Sociological Review, 1965, roč. 30, č. 6, s. 843 - 861. ISSN 0003-1224.

SABE, Collet J. The Crisis in Religious Socialization : An Analytical Propsal. Social Compass, 2007, roč. 54, č. 1, s. 97 - 111. ISSN 0037-7686.

SAK, Petr. Proměny české mládeže. 1. vyd. Praha : Petrklíč, 2002. 291 s. ISBN 80-7229-042-8.

SHERKAT, Darren. Religious Socialization : Sources of Influence and Influences of Agency. In DILLON, M. (ed.) Handbook of the Sociology of Religion. Cambridge : Cambridge University Press, 2003, s. 151 - 163. ISBN 0-5210-0078-5.

SPALOVÁ, Barbora. Zbožnost v režimech pravdy. Biograf, 2004, č. 33, s. 45 - 64. ISSN 1211-5770.

SPOUSTA, Jan. České církve očima sociologických výzkumů. In HANUŠ, J. (ed.) Náboženství v době společenských změn. Brno : MPÚ MU, 1999, s. 73 - 90. ISBN 80-210-2251-5.

SPOUSTA, Jan. Changes in Religious Values in the Czech Republic. Sociologický časopis, 2002, roč. 38, č. 3, s. 345 - 363. ISSN 0038-0288.

TOMKA, Miklos. Contradictions of Secularism and the Preservations of the Sacred. Four Contexts of Religious Change in Communism. In LAERMANS, R., WILSON, B.R., BILLIET, J. (eds.) Secularization and Social Integration. Papers in Honor of Karel Dobbelaere. Leuven : Leuven University Press, 1998a, s. 177 - 189. ISBN 90-6186-932-3.

TOMKA, Miklos. Coping with Persecution. Religious Change in Communism and in Post-Communist Reconstruction in Central Europe. International Sociology, 1998b, roč. 13, č. 2, s. 229 - 248. ISSN 0268-5809.

TOMKA, Miklos. Marginalizace a opozice jako motivy izolacionismu a konzervatismu východoevropského komunismu. In HANUŠ, J. (ed.) Náboženství v době společenských změn. Brno : MPÚ MU, 1999, s. 91 - 109. ISBN 80-210-2251-5.

VÁCLAVÍKOVÁ HELŠUSOVÁ, Lenka ; VÁCLAVÍK, David. Institucionalizovaná podoba religiozity a její projevy v České republice v letech 1989-2000. Religio, 2006, roč. 14, č. 2, s. $173-191$. ISSN 1210-3640. 
VÁCLAVÍK, David. Náboženství a moderní česká společnost. 1. vyd. Praha : Grada Publishing, 2010. 248 s. ISBN 978-80-247-2468-3.

WOHLRAB-SAHR, Monika ; SCHMIDT-LUX, Thomas ; KARSTEIN, Uta. Secularization as Conflict. Social Compass, 2008, roč. 55, č. 2, s. 127 - 139. ISSN 0037-7686.

WOHLRAB-SAHR, Monika ; SCHMIDT-LUX, Thomas ; KARSTEIN, Uta. Forcierte Säkularität. Religiöser Wandel und Generationendynamik im Osten Deutschlands. 1. vyd. Frankfurt am Main : Campus Verlag, 2009. 375 s. ISBN 3-5933-9054-X.

ZRINŠČAK, S. Generations and Atheism : Paterns of Response to Communist Among Different Generations and Countries. Social Compass, 2004, roč. 51, č. 2, s. 221 - 234. ISSN 0037-7686.

\section{Autorka a autor}

Marie Laudátová je studentkou postgraduálního studia sociologie na Katedře sociologie Fakulty sociálních studií Masarykovy univerzity.

Kontakt:100111@mail.muni.cz

Roman Vido je odborným asistentem na Katedře sociologie Fakulty sociálních studií Masarykovy univerzity. Odborně se zabývá sociologií náboženství a sociologickými teoriemi. Kontakt: vido@fss.muni.cz 